\title{
Efficacy and safety of certolizumab pegol plus methotrexate in active rheumatoid arthritis: the RAPID 2 study. A randomised controlled trial
}

\author{
J Smolen, ${ }^{1}$ R B Landewé, ${ }^{2}$ P Mease, ${ }^{3}$ J Brzezicki, ${ }^{4}$ D Mason, ${ }^{5} \mathrm{~K}$ Luijtens, ${ }^{6}$ R F van \\ Vollenhoven, ${ }^{7}$ A Kavanaugh, ${ }^{8}$ M Schiff, ${ }^{9} \mathrm{G}$ R Burmester, ${ }^{10}$ V Strand ${ }^{11}$ J Vencovský, ${ }^{12}$ \\ D van der Heijde ${ }^{13}$
}

- Additional data are published online only at http://ard.bmj. com/content/vol68/issue6

${ }^{1}$ Division of Rheumatology, Department of Internal Medicine III, Medical University of Vienna and 2nd Department of Medicine, Hietzing Hospital, Vienna, Austria; ${ }^{2}$ Department of Internal Medicine/Division of

Rheumatology and Caphri Research Institute, University Hospital of Maastricht, Maastricht, The Netherlands;

${ }^{3}$ Seattle Rheumatology

Associates, Swedish Medical Center, Seattle, Washington,

USA; ${ }^{4}$ Oddzial Reumatologii ul, Wojewodzki Szpital Zespolony, Elblag, Poland; ${ }^{5}$ Research and Development, UCB Inc, Atlanta, Georgia, USA; ${ }^{6}$ UCB Inc, Brussels, Belgium:

${ }^{7}$ Rheumatology Unit, Karolinska Institute, Stockholm, Sweden;

${ }^{8}$ Division of Rheumatology, University of California, San Diego, California, USA;

${ }^{9}$ University of Colorado, Denver, Colorado, USA; ${ }^{10}$ Department of Rheumatology and Clinical Immunology, Charité University Medicine, Berlin, Germany:

${ }^{11}$ Division of Immunology/ Rheumatology, Stanford University, Portola Valley, California, USA: ${ }^{12}$ Institute of Rheumatology, Prague, Czech Republic; ${ }^{13}$ Department of Rheumatology, Leiden University Medical Centre, Leiden, The Netherlands

Correspondence to:

Professor J Smolen, Division of Rheumatology, Medical

University of Vienna, Vienna A1090, Austria; josef.smolen@ meduniwien.ac.at

Accepted 28 October 2008 Published Online First

17 November 2008

\section{UNIOCKRD}

This paper is freely available online under the BMJ Journals unlocked scheme, see http:// ard.bmj.com/info/unlocked.dtl

\section{ABSTRACT}

Background: Certolizumab pegol is a PEGylated tumour necrosis factor inhibitor.

Objective: To evaluate the efficacy and safety of certolizumab pegol versus placebo, plus methotrexate (MTX), in patients with active rheumatoid arthritis (RA). Methods: An international, multicentre, phase 3 , randomised, double-blind, placebo-controlled study in active adult-onset RA. Patients $(n=619)$ were randomised 2:2:1 to subcutaneous certolizumab pegol (liquid formulation) $400 \mathrm{mg}$ at weeks 0,2 and 4 followed by $200 \mathrm{mg}$ or $400 \mathrm{mg}$ plus MTX, or placebo plus MTX, every 2 weeks for 24 weeks. The primary end point was ACR20 response at week 24 . Secondary end points included ACR50 and ACR70 responses, change from baseline in modified Total Sharp Score, ACR core set variables and physical function.

Results: Significantly more patients in the certolizumab pegol $200 \mathrm{mg}$ and $400 \mathrm{mg}$ groups achieved an ACR20 response versus placebo $(p \leqslant 0.001)$; rates were $57.3 \%$, $57.6 \%$ and $8.7 \%$, respectively. Certolizumab pegol 200 and $400 \mathrm{mg}$ also significantly inhibited radiographic progression; mean changes from baseline in $\mathrm{mTSS}$ at week 24 were 0.2 and -0.4 , respectively, versus 1.2 for placebo (rank analysis $p \leqslant 0.01$ ). Certolizumab pegoltreated patients reported rapid and significant improvements in physical function versus placebo; mean changes from baseline in $\mathrm{HAQ}-\mathrm{DI}$ at week 24 were -0.50 and -0.50 , respectively, versus -0.14 for placebo $(p \leqslant 0.001)$. Most adverse events were mild or moderate, with low incidence of withdrawals due to adverse events. Five patients developed tuberculosis.

Conclusion: Certolizumab pegol plus MTX was more efficacious than placebo plus MTX, rapidly and significantly improving signs and symptoms of RA and physical function and inhibiting radiographic progression.

Trial registration number: NCT00175877

Tumour necrosis factor (TNF) has a central role in the pathogenesis of rheumatoid arthritis (RA), mediating both inflammation and joint damage. ${ }^{1-3}$ TNF inhibitors revolutionised the management of RA because these agents improve signs and symptoms and physical function and inhibit structural damage, particularly in combination with methotrexate (MTX) ${ }^{4-7}$ All three TNF inhibitors in clinical use (infliximab, adalimumab and etanercept) have shown similar efficacy in randomised controlled clinical trials. ${ }^{8-12}$ These agents all contain an immunoglobulin G Fc region which extends their half-life in circulation. ${ }^{13}$
Certolizumab pegol is a PEGylated Fab' fragment of a humanised anti-TNF antibody with high affinity to TNF. It lacks an Fc region and may thus avoid potential Fc-mediated effects such as complement- or antibody-dependent, cell-mediated cytotoxicity, which have been seen in vitro, and attachment of the PEG moiety to the Fab' fragment yields a molecule with a plasma half-life of about 2 weeks. ${ }^{14}$ Certolizumab pegol is effective in the treatment of Crohn's disease, ${ }^{15} 16$ and has been shown to significantly improve the signs and symptoms of active RA in phase $2^{17}$ and phase $3^{18}$ trials. This study, Rheumatoid Arthritis PreventIon of structural Damage 2 (RAPID 2), evaluated the efficacy and safety of subcutaneous liquid certolizumab pegol (200 $\mathrm{mg}$ and $400 \mathrm{mg}$ ) plus MTX every 2 weeks compared with placebo plus MTX in patients with active RA despite $\geqslant 6$ months' MTX treatment.

\section{PATIENTS AND METHODS}

\section{Design overview}

RAPID 2 was a 24-week, phase 3, double-blind, randomised, multicentre, placebo-controlled study at 76 international sites (June 2005 to September 2006). Patients were randomised 2:2:1 to one of two regimens of subcutaneous liquid certolizumab pegol (400 mg at weeks 0,2 and 4, followed by 200 or 400 mg every 2 weeks) plus MTX, or placebo (saline) plus MTX. The study was conducted in accordance with good clinical practice and the Declaration of Helsinki and was approved by an institutional review committee at each participating centre. All participating patients provided written informed consent.

Patients who did not show an ACR20 response at both weeks 12 and 14 were to be withdrawn from the study, designated ACR20 non-responders in the primary analysis and allowed to enter an open-label extension study at week 16 with certolizumab pegol $400 \mathrm{mg}$ every 2 weeks.

\section{Participants}

The full inclusion and exclusion criteria are available online as supplementary material. Eligible patients were aged $\geqslant 18$ years with a diagnosis of $R A$, defined by American College of Rheumatology (ACR) 1987 criteria, ${ }^{19}$ of $\geqslant 6$ months' duration but not longer than 15 years, with active disease at screening and baseline. Patients had to have received prior MTX for $\geqslant 6$ months (stable dose $\geqslant 10 \mathrm{mg} /$ week for $\geqslant 2$ months before baseline). 
Figure 1 Patient disposition. *Two patients in the placebo treatment group received CZP and are included in the $200 \mathrm{mg}$ group for safety evaluations. CZP, certolizumab pegol; ITT, intention-to-treat; MTX, methotrexate.

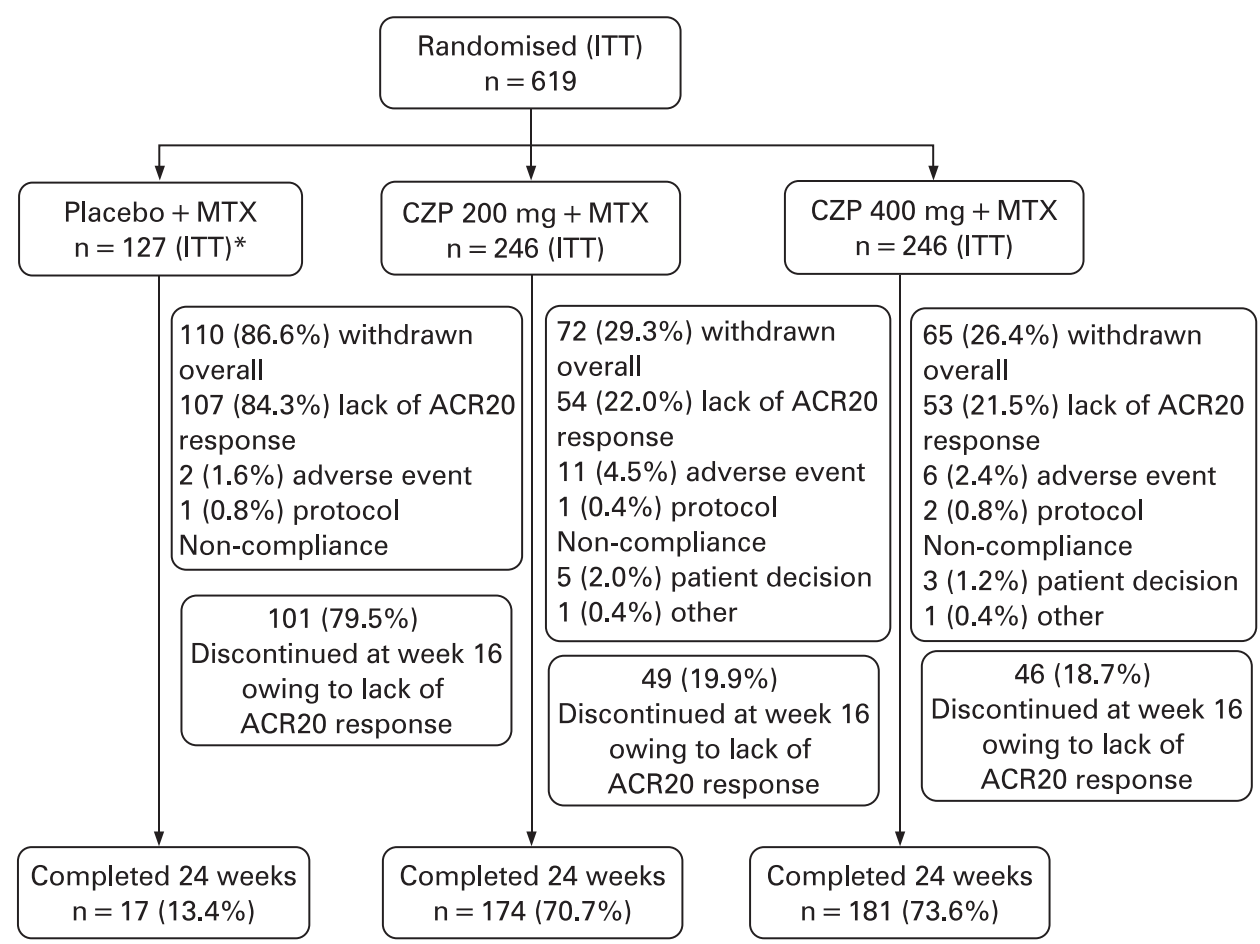

Patients were excluded if they had received any biological agent for RA within 6 months before enrolment (3 months for etanercept and anakinra), had received previous treatment with a biological agent resulting in a severe hypersensitivity or anaphylactic reaction, or had not initially responded to previous anti-TNF therapy. Oral corticosteroids ( $\leqslant 10 \mathrm{mg} /$ day prednisone equivalent) and non-steroidal anti-inflammatory drugs and cyclo-oxygenase- 2 inhibitors were permitted provided that the doses were stable within 28 and 14 days of baseline, respectively and remained stable during the study.

Patients with history of, or positive chest $x$-ray findings for, tuberculosis, or a positive purified protein derivative (PPD) skin test (defined as positive indurations per local medical practice) were excluded. As per protocol, if a positive PPD skin test was assumed by the local investigators to be related to previous bacille Calmette-Guérin (BCG) vaccination and was not associated with clinical or radiographic suspicion of tuberculosis, patients could be enrolled at the discretion of the investigator. In total, 101 patients (16\%) were enrolled with a PPD test $\geqslant 5 \mathrm{~mm}$ at baseline.

\section{Outcomes and follow-up: clinical response}

Assessments were made at baseline, weeks 1, 2, 4, 6, 8, 12, 14, 20 and 24 , or withdrawal. The primary end point was ACR20 response at week 24 , defined as a decrease of $\geqslant 20 \%$ from baseline in the number of tender $(n=68)$ and swollen $(n=66)$ joints, plus a $20 \%$ improvement in three or more of the following: patient's and physician's global assessment of disease activity, patient's assessment of arthritic pain, Health Assessment Questionnaire-Disability Index (HAQ-DI) and serum C-reactive protein or erythrocyte sedimentation rate (ESR). ${ }^{20}$ Secondary efficacy end points at week 24 included ACR50, ACR70, mean change from baseline in van der Heijdemodified Total Sharp Scores (mTSS), ${ }^{21} 22$ Short Form-36 (SF-36) Health Survey, ${ }^{23}$ and individual ACR core set variables. Disease activity was assessed using the Disease Activity Score 28-joint assessment 4 (DAS28 (ESR)4).
Assessment of physical function and health-related quality of life Physical function was assessed using the HAO-DI ${ }^{24}$ at each visit. Health-related quality of life was assessed using the SF-36 Health Survey ${ }^{23}$ physical component summary (PCS), mental component summary (MCS) and physical functioning (PF) domain scores at weeks 0,12 and 24 or withdrawal. Minimal clinically important differences (MCID) were defined as a decrease of $\geqslant 0.22$ points from baseline in the HAQ-DI and improvements $\geqslant 2.5-5.0$ in the PCS and MCS and $\geqslant 5.0-10.0$ in PF scores. ${ }^{25} 26$

\section{Radiographic evaluations}

Radiographic assessments of hands and feet were performed at baseline and at week 24 or withdrawal using the van der Heijde mTSS, which quantifies erosions (erosion score (ES)) and joint space narrowing (JSN). ${ }^{21} 22$ Radiographs were read centrally and blinded (for treatment, visit and patient identification) and independently by two experienced readers. The mean score of two readers was used for analyses.

\section{Safety assessments}

Safety was assessed at all visits, from screening through followup visits 12 weeks after the last dose for patients who did not enter the open-label extension phase.

\section{Statistical analysis}

Sample size was determined on expected differences in the ACR20 responder rate between certolizumab pegol and placebo at week 24 . Five hundred and ninety randomised patients would provide $90 \%$ power to detect a difference of $\geqslant 20 \%$ in ACR20 response at week 24 between each certolizumab pegol group and placebo at a two-sided significance level of $\alpha=0.025$, assuming a placebo rate of $30 \%$.

Efficacy analyses were conducted on the intention-to-treat (ITT) population (all randomised patients). Primary analysis used non-responder imputation; patients who received rescue 
Table 1 Patient demographics and arthritis status at baseline (ITT population)

\begin{tabular}{|c|c|c|c|}
\hline Characteristics & $\begin{array}{l}\text { Placebo }+ \text { MTX } \\
(\mathrm{n}=127)\end{array}$ & $\begin{array}{l}\text { Certolizumab pegol } \\
200 \mathrm{mg}+\text { MTX } \\
\text { (n=246) }\end{array}$ & $\begin{array}{l}\text { Certolizumab pegol } \\
400 \mathrm{mg}+\text { MTX } \\
\text { (n = 246) }\end{array}$ \\
\hline \multicolumn{4}{|l|}{ Demographics } \\
\hline Age (years), mean (SD) & $51.5(11.8)$ & $52.2(11.1)$ & $51.9(11.8)$ \\
\hline Female, $\mathrm{n}(\%)$ & $107(84.3)$ & $206(83.7)$ & $192(78.0)$ \\
\hline Disease duration (years), mean (SD) & $5.6(3.9)$ & $6.1(4.1)$ & $6.5(4.3)$ \\
\hline No of prior DMARDs (excluding MTX), mean (SD) & $1.2(1.2)$ & $1.2(1.3)$ & $1.3(1.2)$ \\
\hline MTX (mg/week), mean (SD) & $12.2(3.3)$ & $12.5(3.6)$ & $12.6(3.7)$ \\
\hline Steroid use, $\mathrm{n}(\%)$ & $76(59.8)$ & $136(55.3)$ & $152(61.8)$ \\
\hline Previous anti-TNF use, $\mathrm{n}(\%)^{*}$ & $2(1.6)$ & $4(1.6)$ & $2(0.8)$ \\
\hline \multicolumn{4}{|l|}{ ACR core components } \\
\hline No of tender joints $(0-68)$, mean (SD) & $30.4(13.4)$ & $30.1(14.5)$ & $30.0(13.9)$ \\
\hline No of swollen joints $(0-66)$, mean (SD) & $21.9(9.7)$ & $20.5(9.6)$ & $21.0(10.2)$ \\
\hline $\begin{array}{l}\text { Physician's global assessment of arthritis (mm), mean } \\
\text { (SD) }\end{array}$ & $65.7(15.1)$ & $64.3(14.6)$ & $62.8(14.0)$ \\
\hline Patient's global assessment of arthritis (mm), mean (SD) & $59.9(21.9)$ & $62.4(20.4)$ & $61.1(19.6)$ \\
\hline Patient's assessment of arthritic pain (mm), mean (SD) & $59.9(22.2)$ & $61.8(19.3)$ & $60.5(20.0)$ \\
\hline $\operatorname{CRP}(\mathrm{mg} / \mathrm{l})$, geometric mean $(\mathrm{CV}) \dagger$ & $13.5(185.8)$ & $14.2(190.8)$ & $13.1(169.9)$ \\
\hline ESR $(\mathrm{mm} / \mathrm{h})$, geometric mean (CV) & $40.8(45.2)$ & $43.7(41.4)$ & $39.1(40.2)$ \\
\hline HAQ-DI, mean (SD) & $1.6(0.6)$ & $1.6(0.6)$ & $1.6(0.6)$ \\
\hline Duration of morning stiffness $(\mathrm{h})$, median (range) & $2.0(0$ to 24.0$)$ & $2.0(0$ to 24.0$)$ & $2.0(0$ to 24.0$)$ \\
\hline \multicolumn{4}{|l|}{ Rheumatoid factor } \\
\hline RF positive ( $\geqslant 14 \mathrm{IU} / \mathrm{ml}), \mathrm{n}(\%)$ & $97(78.2)$ & $186(77.5)$ & $179(75.5)$ \\
\hline RF plasma concentration $(\mathrm{IU} / \mathrm{ml})$, mean (SD) & $135.4(179.6)$ & $145.3(232.7)$ & $149.4(245.5)$ \\
\hline \multicolumn{4}{|l|}{$x$-Ray progression } \\
\hline Estimated yearly progression & 8.7 & 6.6 & 7.4 \\
\hline mTSS, mean (SD) & $46.5(58.6)$ & $39.6(50.1)$ & $46.7(56.0)$ \\
\hline $\mathrm{ES}$, mean (SD) & $23.1(32.1)$ & $19.0(26.8)$ & $21.6(29.7)$ \\
\hline JSN, mean (SD) & $23.4(27.7)$ & $20.6(24.4)$ & $25.1(28.1)$ \\
\hline Disease activity (DAS28 (ESR)), mean (SD) & $6.83(0.87)$ & $6.85(0.84)$ & $6.80(0.79)$ \\
\hline
\end{tabular}

drugs (any non-biological disease modifying antirheumatic drug other than MTX, any other biological agent, intravenous corticosteroids, or intra-articular hyaluronic acid) or withdrew for any reason were considered non-responders from that time point onward. The number of subjects in the summaries varies slightly from the ITT numbers owing to non-imputable missing data. Treatment comparisons for the certolizumab pegol groups with placebo were performed using logistic regression with factors for treatment and region. Treatment effects were estimated with odds ratios and $97.5 \%$ confidence intervals (CIs) obtained by fitting this model. $p$ Values of these treatment effects were also calculated (Wald test). To control the type I error rate further at $5 \%$, a closed test procedure ${ }^{27}$ was used. Safety analyses were conducted on the safety population (all patients who received treatment).

Treatment comparisons for change from baseline at week 24 in individual ACR core set components were analysed using analysis of covariance with last observation carried forward (LOCF) imputation, with region and treatment group as factors and baseline value as covariate. Mean change from baseline mTSS was analysed using analysis of covariance on the ranks, with treatment and region as factors and rank baseline mTSS as covariate. mTSS at week 24 for early withdrawals was estimated by linear extrapolation of the last available value to week 24, assuming disease progression occurred at the same rate between weeks 0 and withdrawal.

Sensitivity analyses were performed under various assumptions on the imputation of missing values, including LOCF imputation of missing scores.

\section{RESULTS}

\section{Patient characteristics and disposition}

Six hundred and nineteen patients were randomised (ITT population); 246 each to certolizumab pegol $200 \mathrm{mg}$ and $400 \mathrm{mg}$ and 127 to placebo. Only 17 (13.4\%) placebo patients completed the study versus $174(70.7 \%)$ and 181 (73.6\%) in the certolizumab pegol $200 \mathrm{mg}$ and $400 \mathrm{mg}$ groups, respectively. More placebo-treated patients $(79.5 \% ; \mathrm{n}=101)$ discontinued treatment owing to lack of ACR20 response at week 16 versus certolizumab pegol $200 \mathrm{mg}(19.9 \%$; $\mathrm{n}=49)$ and $400 \mathrm{mg}(18.7 \%$; $\mathrm{n}=46$ ) (fig 1). Of these, all except one patient from the placebo group entered the open-label extension study.

Patient demographics and baseline characteristics were similar in the three treatment groups and indicated high baseline disease activity (table 1). Baseline demographics were also similar among patients who withdrew at week 16 . 

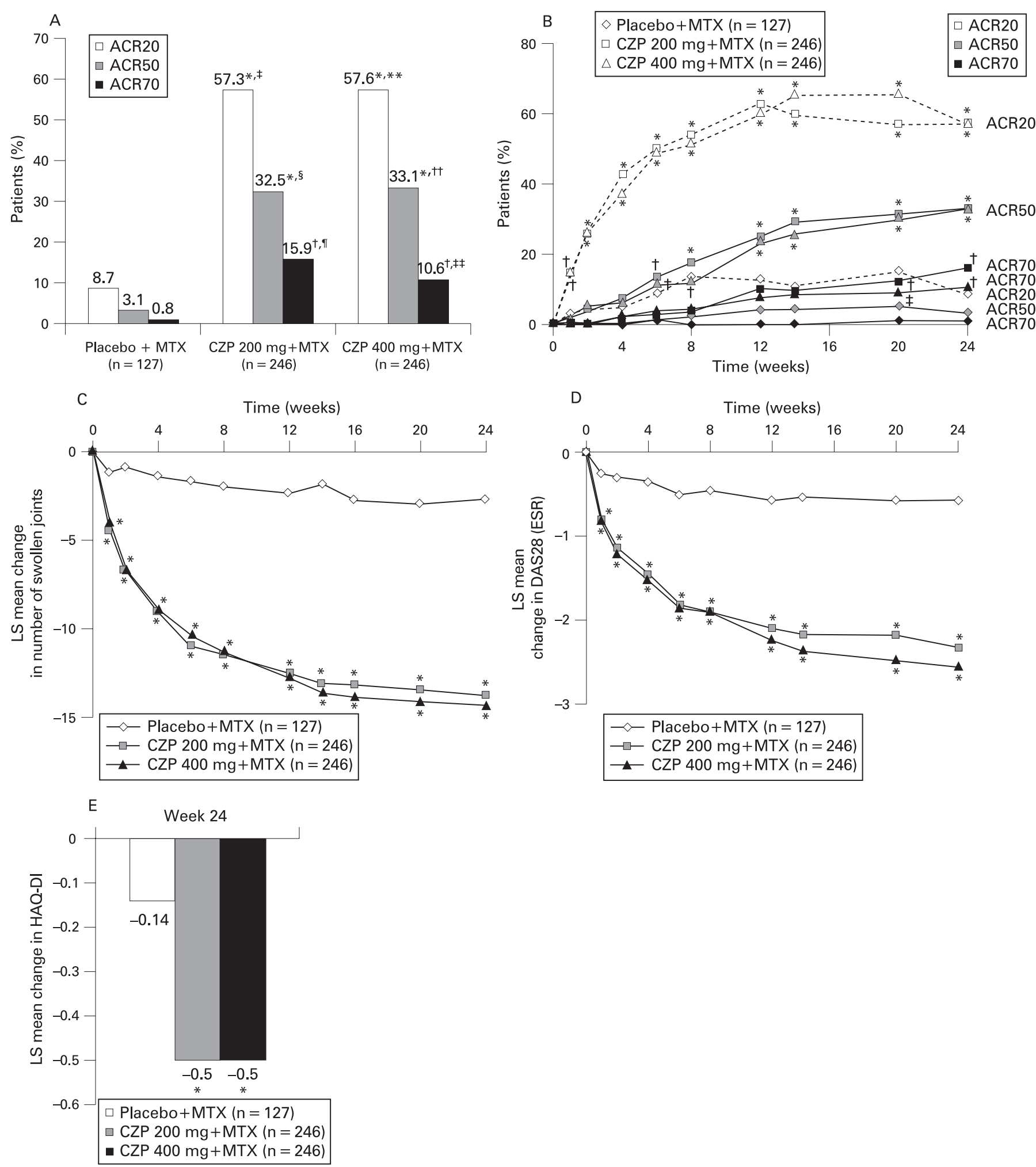

Figure 2 ACR responder rates at week 24 (ITT population-non-responder imputation) and change from baseline in disease signs and symptoms over time (ITT population). (A) ${ }^{*} p<0.001$ versus placebo; $\uparrow p \leqslant 0.01$ versus placebo relate to comparison of odds ratios (ORs) from logistic regression with treatment and region as factors; $₫ \mathrm{OR}=14.4(97.5 \% \mathrm{Cl} 6.7$ to 31.0$) ; \S 0 \mathrm{R}=14.8(95 \% \mathrm{Cl} 5.3$ to 41.6$) ; \quad-\mathrm{OR}=23.8(95 \% \mathrm{Cl} 3.2$ to 175.9$) ;{ }^{* *} 0 \mathrm{R}=14.3$ $(97.5 \% \mathrm{Cl} 6.7$ to 30.8$) ; \dagger+\mathrm{OR}=15.3(95 \% \mathrm{Cl} 5.5$ to 42.9$) ;+\uparrow \mathrm{OR}=15.5(95 \% \mathrm{Cl} 2.1$ to 115.4$)$. (B) ${ }^{*} \mathrm{p}<0.001$ versus placebo; $\dagger p \leqslant 0.01$ versus placebo; $\$ \mathrm{p} \leqslant 0.05$ versus placebo. $(\mathrm{C}-\mathrm{E}){ }^{*} \mathrm{p}<0.001$ versus placebo using ANCOVA with treatment and region as factors and baseline as covariate. LOCF. ACR, American College of Rheumatology; Cl, confidence interval; CZP, certolizumab pegol; DAS28 (ESR), Disease Activity Score 28 (erythrocyte sedimentation rate); HAQ-DI, Health Assessment Questionnaire-Disability Index; ITT, intention-to-treat; LOCF, last observation carried forward; LS, least squares; MTX, methotrexate. 
Table 2 Adjusted mean change and mean percentage improvement from baseline in ACR core components at weeks 4 and 24 (ITT populationLOCF)

\begin{tabular}{|c|c|c|c|c|c|c|}
\hline \multirow[b]{2}{*}{ ACR core components } & \multicolumn{3}{|l|}{ Week 4} & \multicolumn{3}{|l|}{ Week 24} \\
\hline & $\begin{array}{l}\text { Placebo + MTX } \\
(\mathrm{n}=127)\end{array}$ & $\begin{array}{l}\text { Certolizumab } \\
\text { pegol } 200 \mathrm{mg}+ \\
\text { MTX } \\
(\mathrm{n}=246)\end{array}$ & $\begin{array}{l}\text { Certolizumab } \\
\text { pegol } 400 \mathrm{mg}+ \\
\text { MTX } \\
(\mathrm{n}=246)\end{array}$ & $\begin{array}{l}\text { Placebo + MTX } \\
(n=127)\end{array}$ & $\begin{array}{l}\text { Certolizumab } \\
\text { pegol } 200 \mathrm{mg}+ \\
\text { MTX } \\
(\mathrm{n}=246)\end{array}$ & $\begin{array}{l}\text { Certolizumab } \\
\text { pegol } 400 \mathrm{mg}+ \\
\text { MTX } \\
(\mathrm{n}=246)\end{array}$ \\
\hline \multicolumn{7}{|l|}{ Swollen joint count } \\
\hline Adjusted mean change (SE) & $-1.4(0.6)$ & $-9.1(0.5)$ & $-8.9(0.5)$ & $-2.7(0.7)$ & $-13.8(0.5)$ & $-14.2(0.5)$ \\
\hline Mean percentage improvement (SD) & $7.6(28.0)$ & 41.7 (32.8) & $41.4(30.7)$ & $13.3(43.1)$ & $64.2(35.9)$ & $67.8(29.0)$ \\
\hline \multicolumn{7}{|l|}{ Tender joint count } \\
\hline Adjusted mean change (SE) & $-1.8(0.9)$ & $-10.7(0.6)$ & $-11.3(0.7)$ & $-3.8(1.0)$ & $-17.3(0.8)$ & $-19.5(0.8)$ \\
\hline Mean percentage improvement (SD) & $4.4(27.8)$ & $33.4(40.7)$ & $36.0(29.1)$ & $10.5(40.4)$ & $54.8(45.3)$ & $63.6(29.2)$ \\
\hline \multicolumn{7}{|l|}{ Physician's global assessment of arthritis } \\
\hline Adjusted mean change (SE) & $-6.5(1.4)$ & $-24.1(1.1)$ & $-21.9(1.1)$ & $-9.2(1.7)$ & $-34.8(1.3)$ & $-35.6(1.3)$ \\
\hline Mean percentage improvement (SD) & $5.7(26.4)$ & $34.3(24.4)$ & $30.1(25.0)$ & $12.0(30.6)$ & $52.3(28.1)$ & $52.1(29.2)$ \\
\hline \multicolumn{7}{|l|}{ Patient's global assessment of arthritis } \\
\hline Adjusted mean change (SE) & $-2.9(1.7)$ & $-14.6(1.2)$ & $-15.9(1.3)$ & $-4.2(2.0)$ & $-24.5(1.4)$ & $-26.6(1.5)$ \\
\hline Mean percentage improvement (SD) & $-8.5(63.3)$ & $18.1(57.3)$ & $22.4(32.2)$ & $-5.8(61.9)$ & $34.2(46.6)$ & $39.3(37.4)$ \\
\hline \multicolumn{7}{|l|}{ Patient's assessment of arthritic pain } \\
\hline Adjusted mean change (SE) & $-2.8(1.6)$ & $-14.0(1.2)$ & $-14.9(1.2)$ & $-4.7(1.9)$ & $-23.7(1.4)$ & $-26.1(1.4)$ \\
\hline Mean percentage improvement (SD) & $-8.5(59.3)$ & $21.0(29.9)$ & $18.5(55.1)$ & $-8.3(77.4)$ & $35.9(34.9)$ & $37.9(38.5)$ \\
\hline \multicolumn{7}{|l|}{ HAQ-DI } \\
\hline Adjusted mean change (SE) & $-0.05(0.03)$ & $-0.27(0.03)$ & $-0.28(0.03)$ & $-0.14(0.04)$ & $-0.50(0.03)$ & $-0.50(0.03)$ \\
\hline Mean percentage improvement (SD) & $-3.7(54.6)$ & $18.2(26.5)$ & $16.8(34.3)$ & $3.7(59.4)$ & $31.8(38.5)$ & $32.0(35.1)$ \\
\hline $\begin{array}{l}\mathrm{CRP} \text {, adjusted geometric mean }(95 \% \mathrm{Cl})- \\
\text { ratio to baseline }\end{array}$ & $0.89(0.74$ to 1.08$)$ & $0.34(0.30$ to 0.40$)$ & $0.36(0.31$ to 0.42$)$ & $0.92(0.74$ to 1.14$)$ & $0.42(0.35$ to 0.49$)$ & $0.34(0.29$ to 0.40$)$ \\
\hline
\end{tabular}

$\mathrm{p}<0.001$ for certolizumab pegol $200 \mathrm{mg}$ and $400 \mathrm{mg}$ versus placebo for all ACR core components at weeks 4 and 24 based on adjusted mean change from baseline (ANCOVA with LOCF imputation with region and treatment group as factors and baseline value as covariate).

ACR, American College of Rheumatology; ANCOVA, analysis of covariance; CI, confidence interval; CRP, C-reactive protein; HAQ-DI, Health Assessment Questionnaire-Disability Index; ITT, intention-to-treat; LOCF, last observation carried forward; MTX, methotrexate.

\section{Clinical efficacy}

Differences in ACR20 responses at week 24 were significant for certolizumab pegol $200 \mathrm{mg}$ and $400 \mathrm{mg}$ plus MTX, respectively, versus placebo plus MTX (fig $2 \mathrm{~A} ; \mathrm{p} \leqslant 0.001$; response rates: $57.3 \%, 57.6 \%$ and $8.7 \%$, respectively), as were differences in ACR50 and ACR70 responses (fig 2A; $p \leqslant 0.01$ ).

Certolizumab pegol conferred rapid improvement in the signs and symptoms of RA. Significantly higher ACR20 responses were seen with certolizumab pegol as early as week 1 , increased over the first 12 weeks and were maintained through week 24 (fig $2 \mathrm{~B} ; \mathrm{p} \leqslant 0.01$ ). ACR50 and ACR70 responses were significantly higher by weeks 6 and 20 , respectively (fig $2 B ; p \leqslant 0.01$ ). Certolizumab pegol conferred improvements in all ACR core components versus placebo (table 2), including significant reductions in swollen (fig $2 \mathrm{C}$ ) and tender joint counts (data not shown) by week 1 , with continued improvement to week 24. A significant proportion of the total effect of certolizumab pegol was seen by week 4 (table 2).

Treatment with certolizumab pegol plus MTX was also associated with significantly greater improvement in DAS28 (ESR) from baseline versus placebo at all time points $(p<0.001$; fig 2D). At week 24, mean (SD) change was: $200 \mathrm{mg},-2.27$ (1.38); $400 \mathrm{mg},-2.46$ (1.31); placebo, -0.50 (1.05). DAS28 remission (DAS28 $<2.6$ ) was seen in $9.4 \%$ or $8.5 \%$ of patients treated with certolizumab pegol $200 \mathrm{mg}$ or $400 \mathrm{mg}$, respectively, at week 24 , compared with $0.8 \%$ of patients treated in the placebo group ( $p \leqslant 0.05$ vs placebo).

\section{Physical function and health-related quality of life}

Significantly more certolizumab pegol-treated patients reported significant improvements in physical function (HAQ-DI) versus placebo from week 1 to week 24 ( $p<0.001$; fig $2 \mathrm{E}$ ) and clinically meaningful improvements in physical function (HAQ-DI
MCID) from weeks 2 to 24. By week 24, 57\% and 53\% of patients in the certolizumab pegol $200 \mathrm{mg}$ and $400 \mathrm{mg}$ groups, respectively, achieved $\mathrm{HAO}-\mathrm{DI}$ MCID versus $11 \%$ of placebo patients $(p<0.001)$. Patients receiving certolizumab pegol also reported significantly greater improvements in SF-36 PCS, MCS and PF domain scores versus placebo at weeks 12 and 24 $(p<0.001)$. At week 24, adjusted mean changes from baseline in PCS were 5.2 and 5.5 for certolizumab pegol 200 and $400 \mathrm{mg}$, respectively, versus 0.9 for placebo and in PF domain scores were 12.1 and 12.4 , respectively, versus 0.6 for placebo $(p<0.001)$.

Sensitivity analyses of clinical and radiographic efficacy, physical function and health-related quality of life, including LOCF, confirmed the main analyses (data not shown).

\section{Radiographic progression}

Mean changes from baseline to week 24 in mTSS were significantly less in patients treated with certolizumab pegol $200 \mathrm{mg}(0.2 ; 95 \% \mathrm{CI}-0.1$ to 0.6$)$ and $400 \mathrm{mg}(-0.4 ; 95 \% \mathrm{CI}$ -0.7 to -0.1$)$ plus MTX versus placebo plus MTX $(1.2 ; 95 \% \mathrm{CI}$ 0.5 to 2.0 ) (fig $3 \mathrm{~A}$, left graph; $\mathrm{p} \leqslant 0.01$ (200 mg) and $\mathrm{p} \leqslant 0.001$ (400 $\mathrm{mg}$ ) by rank analysis). The negative CI for the certolizumab pegol $400 \mathrm{mg}$ group suggests that some repair may have occurred. ${ }^{28}$ Mean changes from baseline in ES were 0.1 (95\% CI -0.1 to 0.4$)$ and -0.3 (95\% CI -0.6 to -0.1 ) with certolizumab pegol $200 \mathrm{mg}$ and $400 \mathrm{mg}$, respectively, versus placebo $(0.7 ; 95 \%$ CI 0.3 to 1.2 ) ( $p \leqslant 0.01$ (200 mg), $p<0.001$ (400 mg) by rank analysis) (fig 3B). Mean changes from baseline in JSN for certolizumab pegol $200 \mathrm{mg}$ and $400 \mathrm{mg}$ were 0.1 (95\% CI -0.1 to 0.3$)$ and $-0.1(95 \% \mathrm{CI}-0.2$ to 0.0$)$, respectively, versus 0.5 ( $95 \%$ CI 0.1 to 0.9 ) for placebo ( $p \leqslant 0.01$ by rank analysis; fig $3 B$ ). The cumulative probability plots at week 24 show that more patients in the placebo plus MTX group show progression, and 

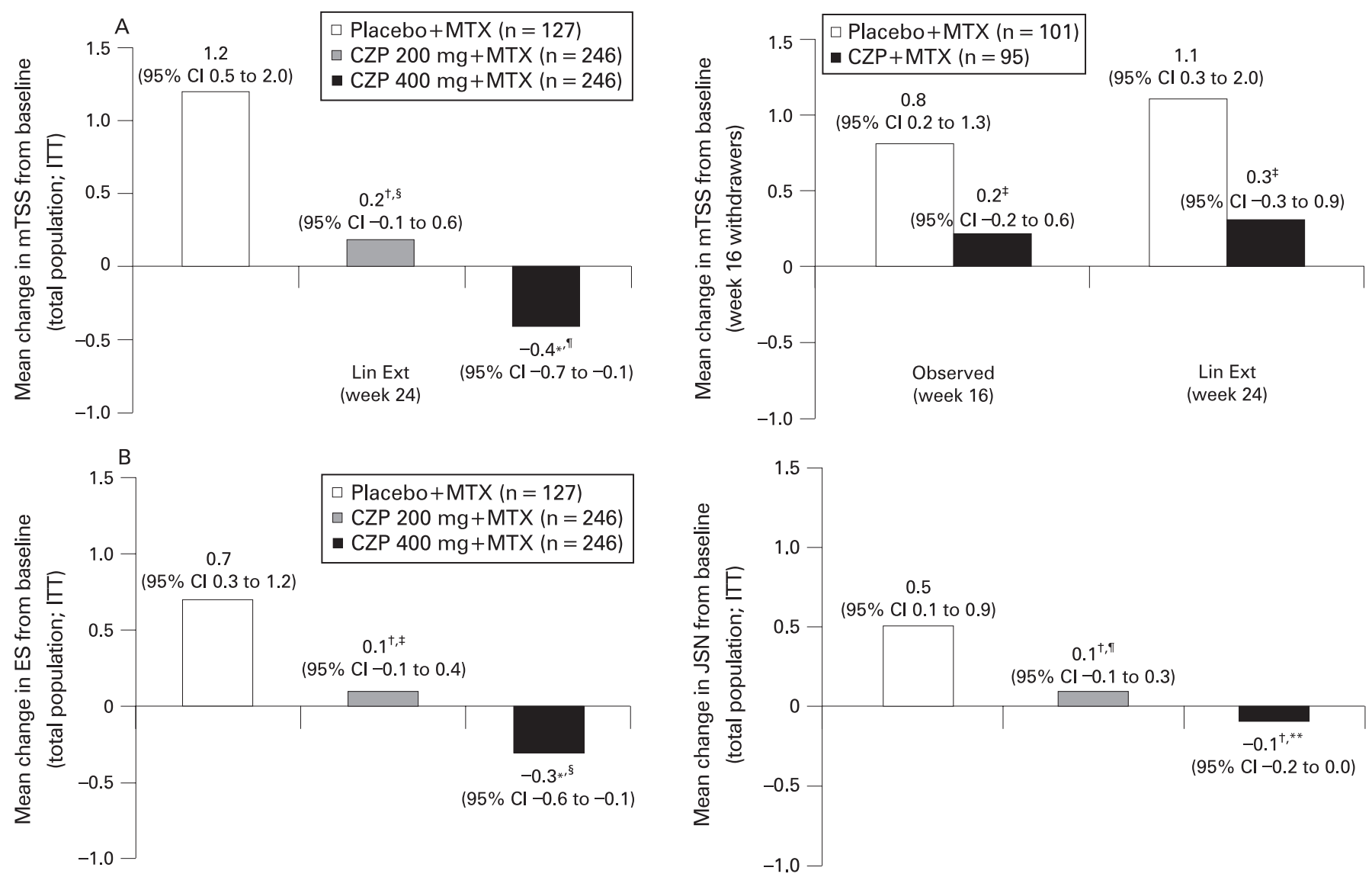

Figure 3 Change from baseline in mTSS, ES and JSN at week 24 (ITT population-linear extrapolation). (A) ${ }^{*} p<0.001 ; \dagger p \leqslant 0.01 ; t p \leqslant 0.05$ versus placebo (ANCOVA on ranks with treatment and region as factors and rank baseline as covariate). Lehmann point estimate of shift (95\% $\mathrm{Cl}$ ): $\S-0.3$ $(-0.8$ to 0.0$) ;-0.7(-1.0$ to 0.0$)$. (B) $* \mathrm{p}<0.001 ; \dagger \mathrm{p} \leqslant 0.01$ versus placebo (ANCOVA on ranks with treatment and region as factors and rank baseline as covariate). Lehmann point estimate of shift (95\% Cl): $50.0(-0.5$ to 0.0$) ; \S-0.5(-0.7$ to 0.0$) ;-0.0(0.0$ to 0.0$) ;{ }^{* *} 0.0(0.0$ to 0.0$)$. ANCOVA, analysis of covariance; Cl, confidence interval; CZP, certolizumab pegol; ES, erosion score; ITT, intention-to-treat; JSN, joint space narrowing; mTSS, modified Total Sharp Scores; MTX, methotrexate.

to a greater extent, than patients treated with certolizumab pegol plus MTX (supplementary fig 1, online only).

In addition, for patients who withdrew at week 16, there was significantly less radiographic progression in certolizumab pegol-treated patients (combined data) than with placebo (fig 3A, right graph). Post hoc linear extrapolation of the week 16 radiographic data suggests that a significant treatment difference would also have been seen at week 24 .

\section{Safety}

Owing to the higher rate of ACR20 non-responders at week 16 in the placebo group, mean treatment exposure was longer in the certolizumab pegol groups than the placebo group. Adverse events occurred in $52.8 \%, 56.0 \%$ and $50.8 \%$ of patients in the placebo, certolizumab pegol $200 \mathrm{mg}$ and $400 \mathrm{mg}$ groups, respectively; most were mild/moderate in intensity (table 3 ). The most frequently reported adverse events included urinary tract infection, haematuria and bacteriuria for placebo; urinary tract infection, upper respiratory tract infection and headache for certolizumab pegol $200 \mathrm{mg}$; and hypertension and headache for certolizumab pegol $400 \mathrm{mg}$ (table 3). Adverse event reporting of hypertension was at the discretion of the investigator and no preset guidelines were defined. Post hoc analysis showed that hypertensive events were related to previous hypertensive status, were transitory and were not related to the study injection.
One case $(0.4 \%)$ of lupus erythematosus rash with certolizumab pegol $200 \mathrm{mg}$ occurred. No injection-site reactions or pain (Medical Dictionary for Regulatory Activities (MedDRA) coded) were reported for placebo. There were $3(1.2 \%)$ or $5(2.0 \%)$ cases of injection-site reactions and 0 or $1(0.4 \%)$ case of injection-site pain in the certolizumab pegol $200 \mathrm{mg}$ or $400 \mathrm{mg}$ groups, respectively. Adverse events leading to discontinuation of the study drug were $1.6 \%$ for placebo and $4.8 \%$ and $2.8 \%$ for certolizumab pegol $200 \mathrm{mg}$ and $400 \mathrm{mg}$, respectively. Anti-certolizumab pegol antibodies were detected in $5.1 \%$ of patients receiving certolizumab pegol plus MTX. The number of antibody-positive patients was too low to identify any statistically or clinically significant antibody effect on response. Nine patients had neutralising antibodies: $5(2.0 \%)$ in the certolizumab pegol $200 \mathrm{mg}$ group and $4(1.6 \%)$ in the $400 \mathrm{mg}$ group.

The incidence of serious adverse events was $3.2 \%$ for placebo and $7.3 \%$ in each certolizumab pegol group. Serious infections occurred in $0 \%, 3.2 \%$ and $2.4 \%$ in the placebo, certolizumab pegol $200 \mathrm{mg}$ and $400 \mathrm{mg}$ groups, respectively. Serious infections included one case each of erysipelas, disseminated tuberculosis, peritoneal tuberculosis, pulmonary tuberculosis, gastroenteritis, postoperative wound infection, tooth abscess and urosepsis with certolizumab pegol $200 \mathrm{mg}$ and one case each of erysipelas, pneumonia and upper respiratory tract infection and two cases each of sinusitis and tuberculosis with $400 \mathrm{mg}$. Five patients in the certolizumab pegol arms developed tuberculosis: three from 
Table 3 Treatment-emergent adverse events (safety population)

\begin{tabular}{|c|c|c|c|}
\hline Adverse events & $\begin{array}{l}\text { Placebo + } \\
\text { MTX } \\
(\mathrm{n}=125)^{*}\end{array}$ & $\begin{array}{l}\text { Certolizumab } \\
\text { pegol } 200 \mathrm{mg}+ \\
\text { MTX } \\
(\mathrm{n}=248)\end{array}$ & $\begin{array}{l}\text { Certolizumab } \\
\text { pegol } 400 \mathrm{mg}+ \\
\text { MTX } \\
(\mathrm{n}=246)\end{array}$ \\
\hline Any treatment-emergent $\mathrm{AE}$ & $66(52.8)$ & $139(56.0)$ & $125(50.8)$ \\
\hline \multicolumn{4}{|l|}{ Intensity } \\
\hline Mild & $45(36.0)$ & $108(43.5)$ & $101(41.1)$ \\
\hline Moderate & $32(25.6)$ & $61(24.6)$ & $57(23.2)$ \\
\hline Severe & $5(4.0)$ & $17(6.9)$ & $14(5.7)$ \\
\hline Related & $23(18.4)$ & $61(24.6)$ & $56(22.8)$ \\
\hline Any infections & $26(20.8)$ & $69(27.8)$ & $53(21.5)$ \\
\hline SAE & $4(3.2)$ & $18(7.3)$ & $18(7.3)$ \\
\hline Serious infections & 0 & $8(3.2)$ & $6(2.4)$ \\
\hline AE leading to death & 0 & $1(0.4)$ & $1(0.4)$ \\
\hline AE leading to withdrawal & $2(1.6)$ & $12(4.8)$ & $7(2.8)$ \\
\hline \multicolumn{4}{|l|}{ Most common $\mathrm{AE} \dagger$} \\
\hline Urinary tract infection & $9(7.2)$ & $11(4.4)$ & $5(2.0)$ \\
\hline $\begin{array}{l}\text { Upper respiratory tract } \\
\text { infection }\end{array}$ & $2(1.6)$ & $11(4.4)$ & $4(1.6)$ \\
\hline Headache & $1(0.8)$ & $9(3.6)$ & $8(3.3)$ \\
\hline Bacteriuria & $4(3.2)$ & $8(3.2)$ & $6(2.4)$ \\
\hline Nasopharyngitis & $1(0.8)$ & $8(3.2)$ & $4(1.6)$ \\
\hline Rheumatoid arthritis & $4(3.2)$ & $7(2.8)$ & $2(0.8)$ \\
\hline Hypertension & $2(1.6)$ & $6(2.4)$ & $9(3.7)$ \\
\hline Haematuria & $5(4.0)$ & $4(1.6)$ & $4(1.6)$ \\
\hline Hepatic enzyme increased & $4(3.2)$ & $3(1.2)$ & $3(1.2)$ \\
\hline AST increased & $5(4.0)$ & $2(0.8)$ & $6(2.4)$ \\
\hline ALT increased & $6(4.8)$ & $1(0.4)$ & $8(3.3)$ \\
\hline
\end{tabular}

Results are shown as number (\%) of patients.

* Two patients in the placebo group received certolizumab pegol $200 \mathrm{mg}$ and were included in the certolizumab pegol 200 mg group for safety evaluations; †treatmentemergent adverse events occurring in $\geqslant 3 \%$ in any group of the safety population.

$A E$, adverse event; ALT, alanine aminotransferase; AST, aspartate aminotransferase; MTX, methotrexate; SAE, serious adverse event.

Russia, one from Poland and one from Latvia. At screening, two of these five patients had PPD reactions of $4-5 \mathrm{~mm}$ with normal chest $x$-ray findings and one patient with a PPD reaction $(6 \mathrm{~mm})$ also had abnormal chest $x$-ray findings at baseline, which were deemed not clinically significant by local investigators. These patients were enrolled into the study by investigator discretion. The length of time from exposure to certolizumab pegol to development of tuberculosis ranged from 58 to 169 days. All patients received treatment for tuberculosis and the study drug was permanently discontinued in four of the five cases. In one case, the patient completed the study.

One case of malignant neoplasm was reported in each of the placebo (bladder cancer), certolizumab pegol $200 \mathrm{mg}$ (testicular cancer) and certolizumab pegol $400 \mathrm{mg}$ (colon cancer) groups. Two patients died during the study, one in the certolizumab pegol $200 \mathrm{mg}$ (myocardial infarction) and one in the $400 \mathrm{mg}$ (fracture, shock) groups; these events were assessed as unlikely to be related to the study drug.

\section{Laboratory interference}

A prolonged activated partial thromboplastin time (aPTT) was seen in the $200 \mathrm{mg}$ and $400 \mathrm{mg}$ dose groups of certolizumab pegol $(4.8 \%$ and $4.9 \%$ of patients, respectively) versus placebo (1.6\%). Additional analyses demonstrated that PEG interferes with the phospholipid component of some commercial assays that measure aPTT, including the HemosIL aPTT-SP-liquid (Instrumentation Laboratory, Lexington, Massachusetts, USA) and PTT-LA (Diagnostica Stago, Parsippany, New Jersey, USA) assays used in this trial.

\section{DISCUSSION}

This trial demonstrated that certolizumab pegol plus MTX significantly improved the signs and symptoms of RA, inhibited progression of joint damage and increased physical function and quality of life versus placebo plus MTX in patients with active RA despite MTX. Statistically significant and clinically meaningful differences between placebo and both certolizumab pegol doses were observed with respect to the primary end point (ACR20 response) and all secondary end points (including ACR50, ACR70, ACR core set variables such as swollen and tender joint counts, changes in DAS28 and DAS28 remission). These clinical benefits were achieved rapidly, as early as 1 week of treatment, in this population of patients with severe disease (91\% with DAS28 $>5.1$ at baseline). Although the weekly dosage of MTX used in this trial was low by US standards, post hoc analyses showed that ACR20/ $50 / 70$ response rates at week 24 were similar in patients who received baseline MTX doses of $10 \mathrm{mg} /$ week, >10-15 mg/week and $>15 \mathrm{mg} /$ week. There were no statistically significant differences in clinical efficacy on any study primary or secondary end points between the two certolizumab pegol dose groups, suggesting that a $200 \mathrm{mg}$ dose every 2 weeks is optimal for treatment.

Both doses of certolizumab pegol plus MTX significantly inhibited the progression of structural joint damage compared with placebo plus MTX, as demonstrated by significantly lower mean changes from baseline in mTSS, ES and JSN scores. Comparable inhibition of progression was seen with both certolizumab pegol doses and there was some suggestion of repair of joint damage in the $400 \mathrm{mg}$ dose group (negative 95\% CI of the change in mTSS).$^{28}$ An additional analysis of the radiographic data from patients who withdrew at week 16 owing to ACR20 nonresponse (per protocol) found that certolizumab pegol had slowed the progression of joint damage in these patients even though they had not achieved an ACR20 response, confirming that certolizumab pegol rapidly inhibits joint damage. These data are also in line with previous findings on a dissociation of inflammation and destruction in the course of anti-TNF plus MTX treatment. ${ }^{29}$ Certolizumab pegol provided rapid, significant and clinically meaningful improvements in physical function and quality of life, with significant changes in HAO-DI at week 1 and in SF-36 PCS, MCS and PF domains at week 12, which continued to improve through to week 24. As functional outcomes are associated with structural damage in progressive RA, ${ }^{30-32}$ treatments that can both improve physical function and inhibit joint damage may help prevent long-term disability. The robustness of all clinical, radiographic and physical function findings were confirmed by sensitivity analyses (data not shown).

Certolizumab pegol plus MTX had an acceptable safety profile with a low incidence of discontinuations due to adverse events. An isolated increase in aPTT was seen for patients treated with certolizumab pegol and placebo in this study. However, no association was seen between increased coagulation assay time and bleeding events. Additional laboratory analyses have shown that this observation was an in vitro phenomenon and that there is no effect on in vivo coagulation function (data not shown). Serious infections, including tuberculosis, were reported more frequently with certolizumab pegol than placebo, consistent with rates associated with other anti-TNF treatments. ${ }^{33}$ Tuberculosis was reported in a total of five patients (all treated with certolizumab pegol) and was partly attributable to insufficient stringency in screening results by local investigators combined with high background rates of tuberculosis. $^{34}$ If current criteria were used to screen for tuberculosis, two of these patients would have been classified as having positive PPD reactions and would have been excluded 
from the study. The incidence of malignancy was low (one patient in each treatment group), with no reported lymphomas.

One limitation of this study was its relatively short duration. Longer-term experience, especially related to safety, will need to be obtained from long-term extension trials and registries. Nevertheless, the study demonstrates that the efficacy and safety of certolizumab pegol is consistent with previously published results for other anti-TNF therapies..$^{5-7}$

The three licensed anti-TNF agents are either monoclonal antibodies (adalimumab, infliximab) or receptor constructs (etanercept) and all contain an immunoglobulin G Fc portion. Interestingly, the data shown here show that the Fc portion, which is lacking in certolizumab pegol, is not necessary for TNF inhibitors to be clinically effective in RA. Thus, the primary mode of action of TNF inhibitors in RA does not appear to involve Fcmediated effects but rather the binding and inactivation of TNF and, probably, reverse signalling, ${ }^{35}{ }^{36}$ which can also be mediated by an Fc-free Fab' molecule such as certolizumab pegol.

In summary, this study demonstrated that certolizumab pegol rapidly and significantly ameliorates clinical signs and symptoms of RA, inhibits progression of structural damage and improves physical function and quality of life in patients with active RA despite MTX. These clinical benefits are associated with a low rate of injection-site reactions and a safety profile consistent with other anti-TNF therapies. Therefore, certolizumab pegol expands the treatment armamentarium for patients with RA.

Acknowledgements: We acknowledge the editorial services of Linda Wychowski and Joanne Vaughan from PAREXEL.

Funding: The RAPID 2 study was fully funded by UCB, Inc.

Competing interests: Declared. JS, RBL, PM, RFvV, AK, MS, GRB, VS and DvdH serve as consultants to UCB, Inc. RBL, AK, MS and DvdH receive research funding from UCB, Inc and GRB and JV have received honorarium from UCB, Inc for speaking. $\mathrm{DM}$ and $\mathrm{KL}$ are employees of UCB, Inc. JB has nothing to disclose.

Ethics approval: Ethics committee approval obtained.

JS had full access to all of the data in the study and takes responsibility for the integrity of the data and the accuracy of the data analysis.

\section{REFERENCES}

1. Feldmann M, Brennan FM, Maini RN. Role of cytokines in rheumatoid arthritis. Ann Rev Immunol 1996;14:397-440.

2. Maini RN, Elliott MJ, Brennan FM, Williams RO, Chu CO, Paleolog E, et al. Monoclonal anti-TNF alpha antibody as a probe of pathogenesis and therapy of rheumatoid disease. Immunol Rev 1995;144:195-223.

3. Redlich K, Schett G, Steiner G, Hayer S, Wagner EF, Smolen JS. Rheumatoid arthritis therapy after tumor necrosis factor and interleukin-1 blockade. Arthritis Rheum 2003:48:3308-19.

4. Furst DE, Breedveld FC, Kalden JR, Smolen JS, Burmester GR, Bijlsma JW, et al. Updated consensus statement on biological agents, specifically tumour necrosis factor $\alpha$ (TNF $\alpha$ ) blocking agents and interleukin-1 receptor antagonist (IL-1RA), for the treatment of rheumatic diseases, 2005. Ann Rheum Dis 2005;64(suppl 4):iv2-14.

5. Maini R, St Clair EW, Breedveld F, Furst DE, Kalden J, Weisman MH, et al. Infliximab (chimeric anti-tumour necrosis factor alpha monoclonal antibody) versus placebo in rheumatoid arthritis patients receiving concomitant methotrexate: a randomised phase III trial. ATTRACT Study Group. Lancet 1999:354:1932-9.

6. Weinblatt ME, Kremer JM, Bankhurst AD, Bulpitt KJ, Fleischmann RM, Fox Rl, et al. A trial of etanercept, a recombinant tumor necrosis factor receptor:Fc fusion protein, in patients with rheumatoid arthritis receiving methotrexate. N Engl J Med 1999;340:253-9.

7. Weinblatt ME, Keystone EC, Furst DE, Moreland LW, Weisman MH, Birbara C, et al. Adalimumab, a fully human anti-tumor necrosis factor alpha monoclonal antibody, for the treatment of rheumatoid arthritis in patients taking concomitant methotrexate: the ARMADA trial. Arthritis Rheum 2003;48:35-45.

8. Alonso-Ruiz A, Pijoan JI, Ansuategui E, Urkaregi A, Calabozo M, Quintana A. Tumor necrosis factor alpha drugs in rheumatoid arthritis: systematic review and metaanalysis of efficacy and safety. BMC Musculoskelet Disord 2008;9:52.

9. Bathon JM, Martin RW, Fleischmann RM, Tesser JR, Schiff MH, Keystone EC, et al. A comparison of etanercept and methotrexate in patients with early rheumatoid arthritis. N Engl J Med 2000;343:1586-93.

10. Keystone EC, Kavanaugh AF, Sharp JT, Tannenbaum H, Hua Y, Teoh L, et al. Radiographic, clinical, and functional outcomes of treatment with adalimumab (a human anti-tumor necrosis factor monoclonal antibody) in patients with active rheumatoid arthritis receiving concomitant methotrexate therapy: a randomized, placebo-controlled, 52-week trial. Arthritis Rheum 2004;50:1400-11.

11. Lipsky PE, van der Heijde DMFM, St Clair EW, Furst DE, Breedveld FC, Kalden JR, et al. Infliximab and methotrexate in the treatment of rheumatoid arthritis. N Engl J Med 2000;343:1594-602.

12. St Clair EW, Wagner CL, Fasanmade AA, Wang B, Schaible T, Kavanaugh A, et al. The relationship of serum infliximab concentrations to clinical improvement in rheumatoid arthritis: results from ATTRACT, a multicenter, randomized, double-blind, placebo-controlled trial. Arthritis Rheum 2002;46:1451-9.

13. Mohler KM, Murray KM, Mann DL, Francis G. Use of targeted anticytokine treatments in heart failure. Circulation 2000;102:E65.

14. Nesbitt A, Fossati G, Bergin M, Stephens P, Stephens S, Foulkes R, et al. Mechanism of action of certolizumab pegol (CDP970): in vitro comparison with other anti-tumor necrosis factor $\alpha$ agents. Inflamm Bowel Dis 2007;13:1323-32.

15. Sandborn WJ, Feagan BG, Stoinov S, Honiball PJ, Rutgeerts P, Mason D, et al. Certolizumab pegol for the treatment of Crohn's disease. N Engl J Med 2007:357:228-38.

16. Schreiber S, Khaliq-Kareemi M, Lawrance IC, Thomson O, Hanauer SB, McColm J, et al. Maintenance therapy with certolizumab pegol for Crohn's disease. N Engl J Med 2007;357:239-50.

17. Choy EHS, Hazleman B, Smith M, Moss K, Lisi L, Scott DGl, et al. Efficacy of a novel PEGylated humanized anti-TNF fragment (CDP870) in patients with rheumatoid arthritis: a phase II double-blinded, randomized, dose-escalating trial. Rheumatology (Oxford) 2002;41:1133-7.

18. Keystone EC, van der Heijde D, Mason D, Landewé R, van Vollenhoven R, Combe B, et al. Certolizumab pegol plus methotrexate is significantly more effective than placebo plus methotrexate in active rheumatoid arthritis. Arthritis Rheum 2008;58:3319-29.

19. Arnett FC, Edworthy SM, Bloch DA, McShane DJ, Fries JF, Cooper NS, et al. The American Rheumatism Association 1987 revised criteria for the classification of rheumatoid arthritis. Arthritis Rheum 1988;31:315-24.

20. Felson DT, Anderson JJ, Boers M, Bombardier C, Furst D, Goldsmith C, et al. American College of Rheumatology. Preliminary definition of improvement in rheumatoid arthritis. Arthritis Rheum 1995;38:727-35.

21. van der Heijde D. How to read radiographs according to the Sharp/van der Heijde method. J Rheumatol 1999;26:743-5.

22. van der Heijde D, Simon L, Smolen J, Strand V, Sharp J, Boers M, et al. How to report radiographic data in randomized clinical trials in rheumatoid arthritis: guidelines from a roundtable discussion. Arthritis Rheum 2002;47:215-8.

23. Ware JE, Kosinski M. SF-36 Physical and Mental Health Summary Scales: manual for users version 1. 2nd ed. Lincoln, Rhode Island, USA: Quality Metric, 2001.

24. Bruce B, Fries JF. The Stanford Health Assessment Questionnaire: a review of its history, issues, progress, and documentation. J Rheumatol 2003;30:167-78.

25. Wells GA, Tugwell P, Kraag GR, Baker PR, Groh J, Redelmeier DA. Minimum important difference between patients with rheumatoid arthritis: the patient's perspective. J Rheumatol 1993;20:557-60.

26. Strand V, Singh JA. Improved health-related quality of life with effective diseasemodifying antirheumatic drugs: evidence from randomized controlled trials. Am J Manag Care 2007;13(suppl 9):S237-51.

27. Koch GC, Gansky SA. Statistical considerations for multiplicity in confirmatory protocols. Drug Inf J 1996;30:523-34.

28. van der Heijde D, Landewe R, Boonen A, Einstein S, Herborn G, Rau R, et al. Expert agreement confirms that negative changes in hand and foot radiographs are a surrogate for repair in patients with rheumatoid arthritis. Arthritis Res Ther 2007:9:R62.

29. Smolen JS, van der Heijde DM, St Clair EW, Emery P, Bathon JM, Keystone E, et al. Predictors of joint damage in patients with early rheumatoid arthritis treated with high-dose methotrexate with or without concomitant infliximab: results from the ASPIRE trial. Arthritis Rheum 2006;54:702-10.

30. Welsing PM, van Gestel AM, Swinkels HL, Kiemeney LA, van Riel PL. The relationship between disease activity, joint destruction, and functional capacity over the course of rheumatoid arthritis. Arthritis Rheum 2001;44:2009-17.

31. Drossaers-Bakker KW, de Buck M, van Zeben D, Zwinderman AH, Breedveld FC, Hazes JM. Long-term course and outcome of functional capacity in rheumatoid arthritis: the effect of disease activity and radiologic damage over time. Arthritis Rheum 1999;42:1854-60.

32. Aletaha D, Smolen J, Ward MM. Measuring function in rheumatoid arthritis: identifying reversible and irreversible components. Arthritis Rheum 2006;54:2784-92.

33. Kroesen S, Widmer AF, Tyndall A, Hasler P. Serious bacterial infections in patients with rheumatoid arthritis under anti-TNF-alpha therapy. Rheumatology (Oxford) 2003; 42:617-21.

34. World Heath Organization. WHO country data: estimated burden of TB. Available at http://www.hpa.org.uk/infections/topics_az/tb/epidemiology/who table1.htm (accessed 18 November 2008).

35. Rigby WF. Drug insight: different mechanisms of action of tumor necrosis factor antagonists-passive-aggressive behavior? Nat Clin Pract Rheumatol 2007; 3:227-33.

36. Mitoma H, Horiuchi T, Hatta N, Tsukamoto H, Harashima S, Kikuchi $Y$, et al. Infliximab induces potent anti-inflammatory responses by outside-to-inside signals through transmembrane TNF-alpha. Gastroenterology 2005;128:376-92. 